Bangladesh J. Bot. 36(2): 145-149, 2007 (December)

\title{
RESPONSE OF CHICKPEA (CICER ARIETINUM L.) TO ZINC AND MOLYBDENUM FERTILIZATION
}

\author{
Hatice Bozoglu*, Huseyin Ozcelik", Zeki Mut and Erkut Pesken \\ Department of Agronomy, Faculty of Agriculture, University of Ondokuz Mayls, \\ Kurupelit, Samsun, Turkey
}

Key words: Chickpea, Seed yield, Zinc, Molybdenum, Response

\begin{abstract}
A field experiment was conducted in Amasya conditions in northern Turkey for two years in order to determine the effect of zinc and molybdenum fertilization on chickpea following a completely randomized block design with three replications. Doses of zinc $\left(\mathrm{Zn}_{0}: 0, \mathrm{Zn}_{1}: 1 \mathrm{ppm}, \mathrm{Zn}_{2}: 2 \mathrm{ppm}\right)$ and molybdenum $\left(\mathrm{Mo}_{0}\right.$ : $\left.0, \mathrm{Mo}_{1}: 0.05 \mathrm{ppm}, \mathrm{Mo}_{2}: 0.1 \mathrm{ppm}\right)$ were applied on leaf when the plants were in vegetative stage. Variation of years on all investigated characters was statistically significant. Applied zinc or molybdenum failed to show any significant effect on any parameter. It was found that effect of $\mathrm{Zn} \times$ Mo interaction was statistically significant $(\mathrm{p}<0.01)$ on the seed yield. The highest seed yield resulted from $\mathrm{Zn}_{2}(2 \mathrm{ppm}) \times \mathrm{Mo}_{0}$ interaction. This was followed by $\mathrm{Zn}_{1}(1 \mathrm{ppm}) \times \mathrm{Mo}_{1}(0.05 \mathrm{ppm})$ and $\mathrm{Zn}_{1} \times \mathrm{Mo}_{2}$ doses showing no statistical differences from each other.
\end{abstract}

\section{Introduction}

Chickpea is highly resistant against heat and is used in narrowing of fields where winter cereals-fallow system is implemented. Turkey is in third place in sowing area and production of chickpea, and in second place in the amount of export in the world. Studies about breeding and cultivation techniques of this plant are necessary for maximization of its yield.

Fertilization is one of the growth techniques that is anticipated in increasing the unit area yield and the quality of crops. The lack of a nutritional element or a nutritional disorder caused by its excess in a culture plant will certainly lead to a decrease in yield (Aktas 2004). Zinc is a micro nutrient that plants need in low amount for normal growth. Reports are available that in half of the samples collected from 25 countries including Turkey, amount of zinc was very low and 14 million hectares of agricultural area in Turkey had zinc deficiency (Cakmak et al. 1995). This situation might be valid not only for zinc but for other micro nutrients as well. Quite a lot of studies have been done around the world but no such satisfactory information about micro nutrients problems in our country is yet been available.

The effect of phosphorus on the yield and yield components of chickpea cv. Giza 1 along with 15 or 30 ppm Fe, Mo, Zn and Mn was investigated in two fields in Egypt during the winter season for two years. Foliar spray of $\mathrm{Zn}$ significantly increased the number of pods and weight of pods per plant, and seed index followed by Mo, Fe and Mn (Sawires 2001). Similar improvement in yields of seed and straw fedan was reported by Abo-Shetaia and Soheir (2001). In view of this, a field experiment was conducted to evaluate the impact of $\mathrm{Zn}$ and Mo fertilization on growth and yield of chickpea for two conceptive years.

\section{Materials and Methods}

A field experiment was conducted to evaluate the effect of zinc and molybdenum on growth and yield of chickpea grown in Amasya province located in the Middle Blacksea region in northern Turkey. Experimental area has an average altitude of $475 \mathrm{~m}$ from the sea has clay loam, neutral $\mathrm{pH}$ and unsalty soil type with semi-dry terrestrial climate.

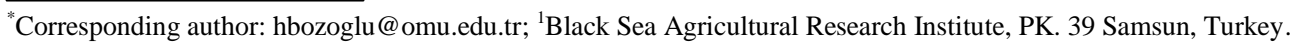


Damla-89 chickpea was used as a test cultivar. The experiment was conducted for two years following a randomized complete block design with three replications on April 8, 1999 and March 22,2000 . Sowing of seeds was made with $35 \mathrm{~cm}$ row space to plots of $8 \mathrm{~m}^{2}$. After considering the results reported by Mut and Gülümser (2001), three doses of each of zinc $\left(\mathrm{Zn}_{0}: 0, \mathrm{Zn}_{1}: 1 \mathrm{ppm}, \mathrm{Zn}_{2}\right.$ $: 2 \mathrm{ppm})$ and molybdenum $\left(\mathrm{Mo}_{0}: 0, \mathrm{Mo}_{1}: 0.05 \mathrm{ppm}, \mathrm{Mo}_{2}: 0.1 \mathrm{ppm}\right)$ were selected. Fertilizers in the form of solution were applied from leaf in vegetative period of chickpea. Diamoniumphosphate was applied as $30 \mathrm{~kg} \mathrm{~N} / \mathrm{ha}$.

Collected data have been subjected to variance analysis in MSTATC package program by being combined over the years. Orthogonal comparison (Cochran and Cox, 1964) was made for treatments.

\section{Results and Discussion}

Results on the effect of zinc and molybdenum on some agronomic characteristics of chickpea cultivar Damla-89 are given in Table 1.

Table 1. Effects of $\mathrm{Zn}$ and Mo on growth and yield of chickpea.

\begin{tabular}{|c|c|c|c|c|c|c|c|c|c|}
\hline \multirow{2}{*}{$\begin{array}{l}\text { Treatments } \\
\quad(\mathrm{ppm})\end{array}$} & \multicolumn{4}{|c|}{1999} & \multicolumn{4}{|c|}{2000} & \multirow{2}{*}{$\begin{array}{c}\mathrm{Zn} \\
\text { Mean }\end{array}$} \\
\hline & $\mathrm{Mo}_{0}$ & $\mathrm{Mo}_{1}$ & $\mathrm{Mo}_{2}$ & Mean & $\mathrm{Mo}_{0}$ & $\mathrm{Mo}_{1}$ & $\mathrm{Mo}_{2}$ & Mean & \\
\hline \multicolumn{10}{|c|}{ Plant height $(\mathrm{cm})$} \\
\hline $\mathrm{Zn}_{0}$ & 32.40 & 34.37 & 33.53 & 33.43 & 51.28 & 48.47 & 49.47 & 49.47 & 41.59 \\
\hline $\mathrm{Zn}_{1}$ & 32.60 & 32.60 & 33.43 & 32.88 & 49.49 & 50.10 & 48.27 & 49.29 & 41.08 \\
\hline $\mathrm{Zn}_{2}$ & 33.83 & 33.70 & 33.73 & 33.76 & 47.33 & 48.3 & 50.21 & 48.61 & 41.18 \\
\hline Mean & 32.94 & 33.56 & 33.57 & $33.36 \mathrm{~b}$ & 49.37 & 48.96 & 49.32 & $49.21 \mathrm{a}^{* *}$ & \\
\hline Mo mean & \multicolumn{3}{|c|}{$\mathrm{Mo}_{0}=41.16$} & \multicolumn{3}{|c|}{$\mathrm{Mo}_{1}=41.26$} & \multicolumn{3}{|c|}{$\mathrm{Mo}_{2}=41.44$} \\
\hline \multicolumn{10}{|c|}{ Pods per plant } \\
\hline $\mathrm{Zn}_{0}$ & 18.43 & 21.33 & 21.70 & 20.49 & 21.21 & 15.93 & 17.01 & 18.05 & 19.27 \\
\hline $\mathrm{Zn}_{1}$ & 19.67 & 17.93 & 18.43 & 18.68 & 22.61 & 23.09 & 18.90 & 21.53 & 20.10 \\
\hline $\mathrm{Zn}_{2}$ & 20.67 & 20.47 & 17.30 & 19.48 & 24.21 & 22.06 & 21.50 & 22.59 & 21.03 \\
\hline Mean & 19.59 & 19.91 & 19.14 & 19.54 & 22.68 & 20.36 & 19.13 & 20.72 & \\
\hline Mo mean & \multicolumn{3}{|c|}{$\mathrm{Mo}_{0}=21.13$} & \multicolumn{3}{|c|}{$\mathrm{Mo}_{1}=20.14$} & \multicolumn{3}{|c|}{$\mathrm{Mo}_{2}=19.14$} \\
\hline \multicolumn{10}{|c|}{ 100-seed weight } \\
\hline $\mathrm{Zn}_{0}$ & 46.37 & 46.70 & 46.37 & 46.48 & 39.63 & 35.43 & 33.13 & 36.07 & 41.27 \\
\hline $\mathrm{Zn}_{1}$ & 46.07 & 46.07 & 47.00 & 46.38 & 43.33 & 32.57 & 40.37 & 38.76 & 42.57 \\
\hline $\mathrm{Zn}_{2}$ & 45.93 & 45.90 & 47.77 & 46.53 & 36.03 & 25.77 & 38.47 & 33.42 & 39.98 \\
\hline Mean & 46.12 & 46.22 & 47.04 & $46.46 \mathrm{a}^{* * *}$ & 39.67 & 31.26 & 37.32 & $36.08 \mathrm{~b}$ & \\
\hline Mo mean & \multicolumn{3}{|c|}{$\mathrm{Mo}_{0}=42.89$} & \multicolumn{3}{|c|}{$\mathrm{Mo}_{1}=38.74$} & \multicolumn{2}{|c|}{$\mathrm{Mo}_{2}=42.18$} & \\
\hline \multicolumn{10}{|c|}{ Seed yield $\left(\mathrm{kg} \mathrm{ha}^{-1}\right)$} \\
\hline $\mathrm{Zn}_{0}$ & 938.2 & 993.2 & 861.8 & 931.0 & 1169.2 & 1208.0 & 997.5 & 112.50 & 1028 \\
\hline $\mathrm{Zn}_{1}$ & 699.2 & 1055.0 & 1034.2 & 929.5 & 1008.0 & 1349.2 & 1321.7 & 122.65 & 1078 \\
\hline $\mathrm{Zn}_{2}$ & 955.0 & 1045.7 & 965.0 & 988.5 & 1495.0 & 1293.0 & 1195.0 & 132.78 & 1158 \\
\hline Mean & 864.2 & 1031.5 & 953.5 & $949.7 b$ & 1224.2 & 1283.5 & 1171.5 & $1226.5 a^{* * *}$ & \\
\hline Mo mean & \multicolumn{2}{|c|}{$\mathrm{Mo}_{0}=1044.0$} & & \multicolumn{3}{|c|}{$\mathrm{Mo}_{1}=1157.5$} & \multicolumn{2}{|c|}{$\mathrm{Mo}_{2}=1062.5$} & \\
\hline \multicolumn{10}{|c|}{ Seed above $9 \mathrm{~mm}$ sieve $(\%)$} \\
\hline $\mathrm{Zn}_{0}$ & 30.33 & 33.87 & 27.23 & 30.48 & 18.59 & 22.26 & 22.22 & 21.02 & 25.75 \\
\hline $\mathrm{Zn}_{1}$ & 28.70 & 30.93 & 29.10 & 29.58 & 19.75 & 16.20 & 18.78 & 18.26 & 23.92 \\
\hline $\mathrm{Zn}_{2}$ & 28.00 & 34.20 & 32.47 & 31.56 & 19.99 & 18.86 & 17.81 & 18.89 & 25.22 \\
\hline Mean & 29.01 & 33.00 & 29.60 & $30.54 \mathrm{a}^{* * *}$ & 19.44 & 19.13 & 19.60 & $19.39 \mathrm{~b}$ & \\
\hline Mo mean & \multicolumn{2}{|c|}{$\mathrm{Mo}_{0}=24.23$} & & \multicolumn{2}{|c|}{$\mathrm{Mo}_{1}=26.06$} & & \multicolumn{2}{|c|}{$\mathrm{Mo}_{2}=24.60$} & \\
\hline
\end{tabular}

$* * \mathrm{p}<0.001$.

Variance analysis showed that application of $\mathrm{Zn}$ and Mo caused a significant change (P < 0.01 ) in plant hight due to variation of years (Table 1). In the first year the plant height was 33.36 $\mathrm{cm}$ and in the second year it increased to 49.21 , in the reason might be due to higher rainfaill (63 
$\mathrm{mm}$ more rainfall) in the second year. Similar results of the same cultivr were reportedly Mut and Gulumser (2001). Individually $\mathrm{Zn}$ and Mo exerted no significant change in height of chickpea plant (Table 1).

Generally, in chickpea, number of pods per plant shows a wide variation between 24 and 160 depending on the genotype and environmental conditions (Akcin 1988). Number of pods per plant is an important yield feature for pulses. The average number of pods/plant were recorded to be 19.54 and 20.4 in the first and second year, respectively (Table 1). Change in pods/plant due to variation in year was not significant. The number of pods/plant showed a close similarly with the findings of Mut and Gulumser (2001) and Bozoglu and Ozcelik (2005). Variance analysis established that year $\times$ zinc interaction has a significant $(p<0.05)$ effect on the number of pods in the second year as evidenced from orthogonal comparison. In the second year, only 18.05 pods per plant were obtained with no $\mathrm{Zn}$. However, this value increased to 21.53 and became statistically significant at 5\% level (Fig.1a).

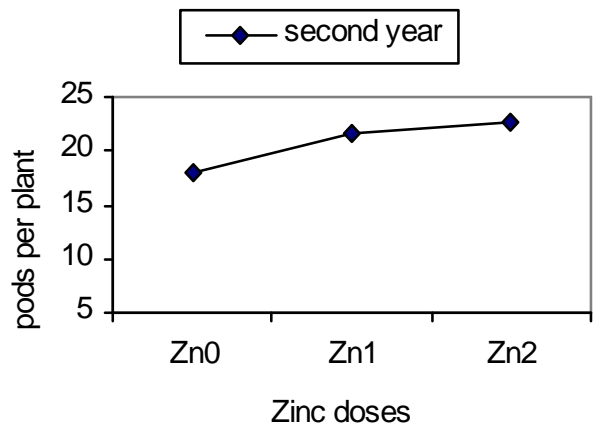

(a)

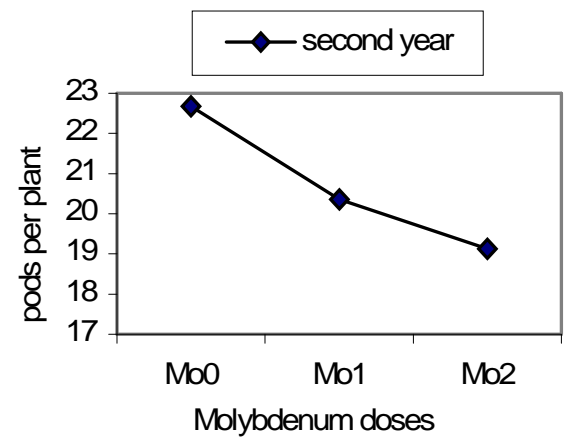

(b)

Fig. 1. The effect of $\mathrm{Zn}$ doses (a) and Mo doses (b) on number of pods per plant in 2000.

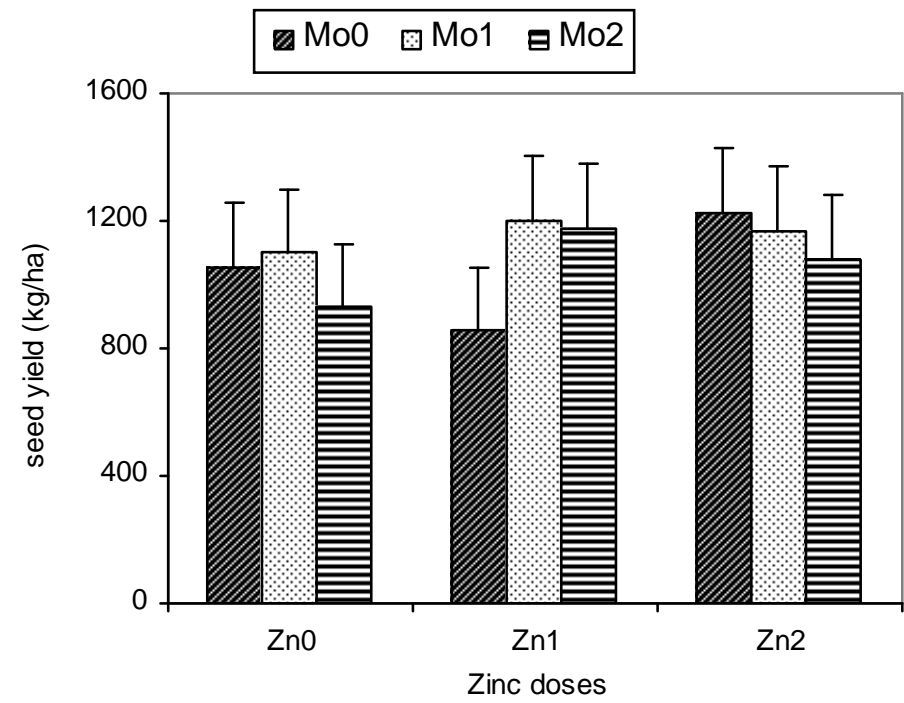

Fig. 2. The effect of $\mathrm{Zn} \times$ Mo interaction on the seed yield.

When $\mathrm{Zn}$ at the rate of $2 \mathrm{ppm}$ was applied, although the number increased to 22.59 but was not significant. Results showed that Mo $\times$ year interaction was significant $(p<0.05)$ and a 
decrease in number of pods was seen with an increase in amount of Mo dose. Increase in Mo from $\mathrm{Mo}_{0}$ to $\mathrm{Mo}_{2}$, the number of pods decreased significantly ( $<$ < 0.05) from 22.68 to 19.13 (Fig.1b). Contrary to this, Aktas (2004) reported that $0.1 \mathrm{ppm}$ Mo is essential for symbiotic process for many pulse plants.

The weight of 100 seed was $46.46 \mathrm{~g}$ in the first year and it decreased to $36.08 \mathrm{~g}$ in the second year (Table 1). This difference between the years was significant (Table 1). Significant statistical difference $(\mathrm{p}<0.01)$ was observed between years in seed yield. While in the first year $949.7 \mathrm{~kg} / \mathrm{ha}$ seed yield was obtained. However, in the second year, this value increased to $1226.5 \mathrm{~kg}$. According to statistical data of FAO in Turkey, average seed yield of chickpea is $940 \mathrm{~kg} / \mathrm{ha}$. The region where the experiment was set up is an ideal field for chickpea cultivation in terms of its ecological and soil condition. If climatic conditions go well, yield can exceed the country average. Applicatyion of $\mathrm{Zn}$ showed an increase in yield with rate but the increase was not statistically significant. As year averages, the yield of Damla-89 chickpea was $1028,1078,1158.2 \mathrm{~kg} / \mathrm{ha}$ due to application of $\mathrm{Zn}(2 \mathrm{ppm})$ (Table 1). Supply of Mo resulted an increase in yield up to $0.05 \mathrm{ppm}$ and thereafter a reduction in the same was occurred $\left(\mathrm{Mo}_{0}: 1044, \mathrm{Mo}_{1}: 1157.5, \mathrm{Mo}_{2}: 1062.5 \mathrm{~kg}\right)$. The effect of $\mathrm{Zn} \times$ Mo interaction on the seed yield was significant $(\mathrm{p}<0.01)$ (Fig. 3). The highest seed yield was obtained from $\mathrm{Zn}_{2} \times \mathrm{Mo}_{0}$ treatment $\left(1225 \mathrm{~kg} / \mathrm{ha}\right.$ ), it was followed by $\mathrm{Zn}_{1} \times \mathrm{Mo}_{1}$ and $\mathrm{Zn}_{2} \times \mathrm{Mo}_{1}$ and these effect were not significantly different from each other (Fig. 2). The lowest seed yield was obtained from $\mathrm{Zn}_{1} \times \mathrm{Mo}_{0}(853.8 \mathrm{~kg} / \mathrm{ha})$ treatment (Fig. 3a). Orthoganal comparison revealed that linear effect was not significant. However, quadratic effect was found to be significant at $1 \%$ level (Fig. $3 \mathrm{a}$ ). $\mathrm{Zn}_{1} \times \mathrm{Mo}_{0}$ interaction showed that zinc was more effective to

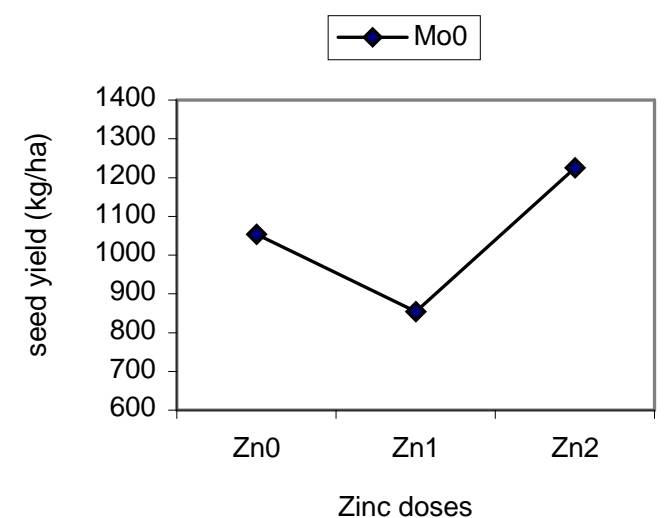

Zinc doses

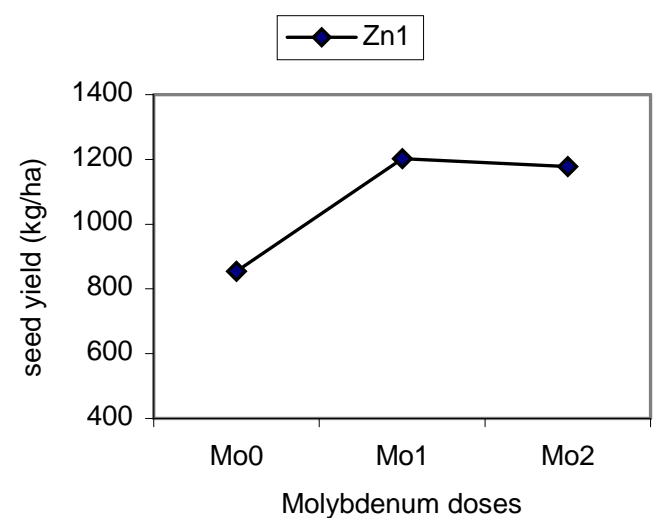

(a) (b)

Fig. 3. The effect of $\mathrm{Zn}$ (a) and Mo (b) doses in presence of $\mathrm{Zn}_{1}$ dose on seed yield of chickpea.

increase the yield than molybdenum. However, if zinc is used with molybdenum, it should be given in a lower dose, but if used without molybdenum, it should be given in a higher dose. This situation presented itself in orthogonal comparison of zinc doses in the treatment without molybdenum (Fig. 3a). Linear and quadratic effects became statistically significant at 1 and 5\% level, respectively. If both elements used together $1 \mathrm{ppm} \mathrm{Zn}$ showed the best result with $0.05 \mathrm{ppm}$ molybdenum (Fig. 3b). Balwant et al. (1984), in India, observed that inoculation, and Mo and Zn treatment increased stem, dry matter and nitrogen content of plant; yield increased with $2 \mathrm{ppm}$ and decreased with 4 ppm Zn.

In Turkey, the grains of treaded chickpea cultivars are divided into three sizes which are very large, large and medium, and the largest ones should be above $9 \mathrm{~mm}$ sieve (Sehrali 1988). Results 
showed a significant effect $(\mathrm{p}<0.01)$ of years on the percentage of seeds above $9 \mathrm{~mm}$ sieve covering $30.54 \%$ in the first year and this value decreased to $19.39 \%$ in the second year. This was reflected in the weight of 100 seed in the first year (Table 1).

\section{References}

Abo-Shetaia, A.M. and A.M. Soheir. 2001. Yield and yield components responses of chickpea (Cicer arietinum L.) to phosphorus fertilization and micronutrients. Arab-Universities J. Agric. Sci. 9(1): 235243

Akcin, A. 1988. Yemeklik Tane Baklagiller. Selçuk Üniv. Ziraat Fak. Yayın No. 8, Konya.

Aktas, M. 2004. Bitkilerde beslenme bozuklukları ve tanınmaları. (Identification and description of plant nutrition disorders). 3. Ulusal Gübre Kongresi Tarım-Sanayi-Çevre. 1-13 Ekim 2004, Tokat, s 11181186.

Balwant, S., R.D. Laura and V.K. Gupta.1984. Influence of Mo, Zn and Rhizobium inoculation on dry matter yield and nitrogen content in Chickpea (Cicer arietinum L.). International J. Trop. Agric. 2(2): 159-165.

Bozoglu, H. and H. Ozcelik. 2005. Nohutta (Cicer arietinum L.) Bazı Özelliklerin Genotip $\times$ Çevre Interaksiyonları ve Stabilitelerinin Belirlenmesi. (An investigation on the determination of stability and genotype $\times$ environment interactions of some characters. In: Chickpea (Cicer arietinum L.). GAP IV. Tarım Kongresi 21-23 Eylül 2005, I. Cilts: 834-839.

Cochran, W. and G.M. Cox. 1964. Experimental Designs. John Wiley Inc. New York, p. 611.

Cakmak, I., B. Torun, B. Erenoglu, M. Kalaycı, A. Yılmaz, H. Ekiz and H. Braun. 1995. Türkiye'de toprak ve bitkilerde çinko eksikliği ve bitkilerin çinko eksikliğine dayanıklılık mekanizmaları. Türk Tarım ve Ormancılık Dergisi, Ankara.

Mut, Z. and A. Gulumser. 2001.Bakteri aşılaması, çinko ve molibden uygulamalarının Damla-89 nohut çeşidinin bazı morfolojik özellikleri ve tane verimine etkileri. (The effect of bacteria inoculation, zinc and molybdenum applications on seed yield and some morphological characteristics of Damla-89 Chickpea cultivar). Ondokuz-Mays-Univ.,-Ziraat-Fakultesi-Dergisi. 16(2): 1-10.

Sawires, E. S. 2001. Effect of phosphorus fertilization and micronutrients on yield and yield components of chickpea (Cicer arietinum L.). Ann. Agric. Sci. Cairo. 46(1): 155-164.

Sehrali, S. 1988. Yemeklik Tane Baklagiller. Ankara Üniv. Zir. Fak. Yay. 1089, Ders Kitabı, 314,s 435.

(Manuscript received on 27 September, 2006; revised on 15 April, 2007) 